\title{
The Idea of Supreme Peace (Taiping) in Premodern Chinese Philosophies of History
}

\author{
Dawid ROGACZ*
}

\begin{abstract}
The paper examines the development of the idea of Supreme Peace (taiping 太平) in premodern Chinese philosophies of history. It is shown that while Daoists identified it with the pristine unity of humans and nature, Han Confucians equated Supreme Peace with the harmonious social system under the rule of one of the first Chinese emperors or Confucius. In the latter case, the notion of taiping was reduced to a descriptive category, which was then employed by historiography but ridiculed in the critical thought of Wang Chong. With Huainanzi and the Xiang'er commentary to Laozi, the Daoists started to argue that it is possible to restore the Supreme Peace under new historical conditions. This was systematically developed in the Scripture of Supreme Peace (Taipingjing), which offered a detailed depiction of the future era of equality and freedom. However, after this radicalization, the idea of taiping was utilized by imperial propaganda and disappeared from the dominant philosophical discourse. An exception to this rule was Li Gou (10091059), who envisaged Supreme Peace as an ideal socio-economic system resulting from endowing peasants with land and money. A similar vision was expressed by Gong Zizhen (1792-1841), for whom Supreme Peace had to entail land equalization and the reduction of social inequalities. Similarly to Taipingjing, however, Gong Zizhen described taiping as the culmination point of the increase of human knowledge. With such an approach, the premodern Chinese views of Supreme Peace became noticeably close to Western progressivism, and therefore inspired the utopian project of Kang Youwei.
\end{abstract}

Keywords: taiping, Supreme Peace, Han philosophy, millenarianism, New Text Confucianism

\section{Ideja velikega miru (taiping) v zgodovini predmodernih kitajskih filozofij Izvleček}

Članek proučuje razvoj ideje velikega miru (taiping 太平) v zgodovini predmodernih kitajskih filozofij. Medtem ko so daoisti idejo velikega miru povezovali s pristno enotnostjo človeka in narave, so jo konfucijanci iz dinastije Han enačili s harmoničnim družbenim sistemom pod vlado enega izmed prvih kitajskih cesarjev ali Konfucija. Pri tem je bil pomen velikega miru zreduciran na deskriptivno kategorijo, sicer uporabljeno v zgodovinopisju,

* Dawid ROGACZ, Faculty of Philosophy, Adam Mickiewicz University in Poznań (Poland).

Email address: dawid.rogacz@amu.edu.pl

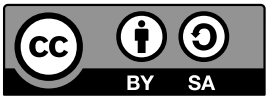


ki pa jo je kritični mislec Wang Chong zasmehoval. V knjigi Huainanzi in Komentarjih Xiang'er h knjigi Laozija so daoisti začeli trditi, da je mogoče idejo velikega miru ponovno oživiti v novih zgodovinskih okoliščinah. To so nadalje sistematično razvili v knjigi Klasik velikega miru (Taipingjing), v kateri so podali podroben opis prihodnje dobe enakosti in svobode. Vendar je po tej radikalizaciji ideja velikega miru pristala v rokah cesarske propagande in s tem izginila iz prevladujočega filozofskega diskurza. Izjema je bil Li Gou (1009-1059), ki si je idejo velikega miru zamislil kot idealen družbeno-ekonomski sistem, $v$ katerem kmetje dobijo zemljo in denar. Podobno vizijo je imel tudi Gong Zizhen (1792-1841), ki je menil, da mora veliki mir voditi v enakost zemljišč in zmanjševanje družbenih neenakosti. Veliki mir je opisal kot vrhunec povečanja človeškega znanja, s tem pristopom pa se je predmoderni kitajski pogled na veliki mir opazno približal zahodnemu progresivizmu, zaradi česar je navdihnil utopični projekt Kang Youweija.

Ključne besede: taiping, veliki mir, filozofija dinastije Han, milenarizem, novi teksti konfucianizma

\section{Introduction}

The idea of Supreme Peace (taiping 太平) is one of the core concepts of the classical Chinese philosophy of history and various attempts at its implementation had a tremendous influence upon Chinese history itself, from the first peasant rebellions up to the Taiping Rebellion in the nineteenth century. As a conceptual expression of the future social ideal, the notion of taiping was taken up by modern Chinese thinkers, forming one of the bridges between premodern and modern Chinese historical thinking, and was an idea which early on served to familiarize China with the Western concept of progress. As such, it also challenges the stereotype that linear views of history were alien to Chinese thought. It is therefore surprising that to date there has been no paper dedicated to the systematic treatment of this notion, whereas those few studies which seem to deal with the topic neglect a philosophical analysis of this category. Timoteus Pokora's seven-page essay on the origins of the concepts of taiping and datong (大同, great unity) (Pokora 1961) is, despite its title, a textual history of one Daoist work. Vincent Shih's monograph on the ideology of the Taipings and its sources focuses, in turn, on the Confucian-rooted ideas of Heaven, spirit, human nature, and rituals, discussing the Confucian approach to the category of taiping on only two pages, without mentioning its Daoist understanding (Shih 1967, 165-214, 277-80). Some references to the ancient Chinese understanding of taiping can be found in Barbara Hendrischke's introduction to her translation of the Scripture of Supreme Peace (Taipingjing 太平經) (Hendrischke 2007, 6-14), but they are not systematic and do not go beyond that period. The following paper aims to fill this research gap. 
However, it should first be noted that it would be quite misleading to believe that there exists one, pan-Chinese understanding of the idea of Supreme Peace that subsequently clashes or merges with the "Western" concept of progress. Ideas have their own history, and this also applies to the notion of taiping, the evolution of which is analysed in this essay. Due to limited space, I focus on the classical evocations of this ideal, putting aside their relation to modern Chinese encounters with the utopian projects of Christianity, socialism, and Marxism. In addressing these issues, the paper pays particular attention to differences between Daoist and Confucian formulations of taiping, which are here portrayed as two parallel developments of this idea. Whereas the most complete exposition of the Daoist vision of taiping comes from the early medieval Scripture of Supreme Peace, the Confucian conception of Supreme Peace was fully developed only by Gong Zizhen 竟 自珍 (1792-1841), whose thought is discussed in the last part of the paper. In conclusion, it is argued that in spite of the internal diversity of premodern Chinese views on taiping, there are certain common points among these conceptions, which opens up new directions for further comparative research.

\section{Early Daoist Conceptualizations of the Idea of Supreme Peace}

The first philosophical evocations of the ideal of Supreme Peace were from the outset characterised by a certain dichotomousness, as they functioned within either Daoist or Confucian conceptual frameworks. Of course, as Karyn Lai (2015) reminds us, a distinction between Confucianism and Daoism was made during the Han dynasty and, in spite of many differences, both philosophies shared the image of an individual always entangled in relations with others and the surrounding environment. On the other hand, the first visions of Supreme Peace were not formulated prior to Han times (202 BCE-220 CE), and this means that the ambiguous relation between Daoist and Confucian discourses during that period translates into discrepancies and similarities within the subsequent conceptions of taiping.

The notion of Supreme Peace does not appear in any Chinese historical and philosophical writing that emerged, in whole or for the most part, in the Warring States Period (476-221 BCE). It is not to be found in four out of five later Classics: the Documents (Shu 書), Songs (Shi 詩), Changes of the Zhou (Zhouyi 周易) and, most importantly, the Springs and Autumns (Chunqiu 春秋). It is also missing in the founding works of the line of scholars (rujia 儒家), known in the West under the name of Confucianism, namely in the Analects (Lunyu 論語) attributed to Confucius (Kongzi 孔子, 551-479 BCE), Master Meng (Mengzi 孟子), and 
Master Xun (Xunzi 荀子). The concept was also unknown to the authors of Master Mo (Mozi 墨子), the only preserved work of the Mohist school, and to the authors of Master Sun's Art of War (Sunzi bingfa 孫子兵法). Master Han Fei (Hanfeizi 韓 非子) makes two enigmatic allusions to "scholars of [the days of] Supreme Peace" (taiping zhi shi 太平之士), but this is all we can find in the so-called Legalist (fajia 法家) texts.

The earliest reference to the category of taiping comes from the Daoist work Zhuangzi 莊子, precisely its “external chapters” (waipian 外篇), which according to Chen Guying $(2016,110)$ were authored by a later generation of the disciples of the historical Zhuang Zhou 莊周 (c. 369-286 BCE). ${ }^{1}$ Importantly, it already introduces a genuinely Daoist vision of Supreme Peace:

The ancients who illuminated the great Dao, first unclouded nature and only then the Way and power; when the Way and power were already illuminated, then came charity and righteousness (...) This is what is meant by Supreme Peace, the epitome of order. (Zhuangzi 13:4/471)

This concise fragment pertains to another passage of Zhuangzi, which puts flesh on the view of history related to the taiping ideal:

Power continued to decline, and then Yao and Yu took control of the world. They initiated a strand of ruling by transformation, defiling purity and shattering simplicity. The Way was abandoned for the sake of goodness, whereas power was substituted with morals. After this, they forsook their nature and followed their minds, minds were joining minds in associating their knowledge, but were not able to bring stability to the world. After this, culture was added, and breadth was piled on top. Culture destroyed the substantial; breadth drowned the mind; as a result, the people began to be confused and disordered. They had no way to return to their nature and feelings, to return to the Beginning. From this we see that the world has lost the Way and the Way has lost the world; the world and the Way have lost each other. (Zhuangzi 16:2/551-552) ${ }^{3}$

1 Esther Klein (2010) argues that the entire Zhuangzi was created under the Han.

2 故古之明大道者, 先明天而道德次之, 道德已明而仁義次之 (...) 此之謂太平, 治之至 也。All translations are my own, unless the translator is mentioned. Page number according to the quoted/cited edition.

3 德又下衰, 及唐、虞始為天下, 興治化之流, 澆淳散朴, 離道以善, 險德以行, 然後去性 而從於心。心與心識知而不足以定天下, 然後附之以文, 益之以博。文滅質, 博溺心, 然 後民始惑亂, 無以反其性情而復其初。由是觀之, 世喪道矣, 道喪世矣。 
The era of Supreme Peace, as understood in Zhuangzi, was a kind of paradise: a state of perfect and in essence prehistoric unity between humans and nature, which was abandoned by the creation of culture along with its normative order (goods, morals), which set people back from the Way of living in accordance with the course of things. There is no doubt, however, that this paradise had been irretrievably lost, and there are no ideas in Zhuangzi on how to break this tragic historical deadlock.

Some general hints about possible ways of restoring the state of unity with nature appear in Daoism, starting with the work Huainanzi 淮南子 (c. 139 BCE). Not without some influence from Legalism, Huainanzi calls not so much for a return to the original state of harmony that has been lost once and for all, as for recreating harmony under new circumstances, taking account of all cultural innovations that have occurred along the way (Huainanzi 11:17/1157). ${ }^{4}$ Charles Le Blanc $(1985,209)$ compares it to the "wave" pattern of history in Christian eschatology, which, however, misrepresents the message of Huainanzi. First, the restoration of unity with nature is possible only by adapting to the tendency ( $s h i$ 勢) of the development of things, and in this sense it is impossible to foresee the exact shape of the upcoming epoch (Huainanzi 9:13/931). ${ }^{5}$ Second, both the tendency and the future unity are essentially inner-worldly. As Anna Seidel $(1984,163)$ aptly observes, "these early formulations of the state of Great Peace differ from Western notions about the messianic age insofar as they do not imply any total break, any total discontinuity with the relative conditions of the present". Finally, the advent of this future era does not hinge on the will of any god, but depends entirely on the actions of the sovereign and therefore does not have to come about at all. In fact, Huainanzi rather pessimistically concludes:

Ancient generations nurtured the root, whereas later generations serve the branches. That is why Supreme Peace cannot yet arise. If a ruler who wishes to govern well does not appear in every age, and a minister who can accompany him in ordering things does not appear even once in ten thousand [officials], and we expect them to encounter each other, then this is a chance that does not occur even once in a thousand years. (Huainanzi 20:16/2074) ${ }^{6}$

4 是故世異則事變, 時移則俗易。故聖人論世而立法, 隨時而舉事。尚古之王, 封于泰山, 禪于梁父。七十餘聖, 法度不同, 非務相反也, 時事異也。

5 夫推而不可為之勢, 而不修道理之數, 雖神聖人不能以成其功, 而況當世之主乎!

6 上世養本, 而下世事末, 此太平之所以不起也。夫欲治之主不世出, 而可與興治之臣不萬 一, 以萬一求不世出, 此所以千歲不一會也。 
In this way, Huainanzi is actually much closer to Zhuangzis defeatism than to eschatological confidence about future salvation.

Later Daoist references to the idea of Supreme Peace come from Eastern Han commentaries to the Old Master (Laozi 老子), which in itself does not yet contain any references to taiping, including its versions from the Mawangdui and Guodian tombs. Heshang Gong's 河上公 commentary to Laozi (first century CE) describes Supreme Peace as a time when there was no difference between the noble and the lowly, people lived to a grand old age without suffering any harm, as the Way they cultivated themselves did not inflict any damage on the gods (Heshang Gong Laozi 35/139; 55/211). Analogously to Huainanzi, it is claimed that in the era of Supreme Peace each human being practiced their own purity and neither knew nor even desired to know such things as charity (ren 仁), righteousness, integrity, and correctness (Heshang Gong Laozi 18/73). ${ }^{8}$ But there is no recipe there, not even an idea, of how to reclaim that state. Similar depictions can be found in the Xiang'er 想爾 commentary to Laozi authored by Zhang Lu 張魯 (d. 216)-a leader of the religious Way of Celestial Masters (Tianshidao 天師道), with the difference that Xiang'er invokes a deified Laozi, who descends to call on humans to work to restore Supreme Peace (see Puett 2014,14-18). Another text associated with this sect, Commands and Admonitions for the Line of Great Dao (Da Daojia lingjie 大道家令戒), assures its followers: “you will see Great Peace; you will pass through the catastrophes unscathed and become the seed people of the later age", but then reminds them: "people must aid Heaven in bringing about Great Peace through their actions" (Bokenkamp 1999, 173, 176-77). In this way, however, a quasi-messianic faith in the ruler becomes replaced with faith in the people, which, along with a hitherto unknown conviction about the still increasing deterioration of the world, had a huge impact upon the Daoist conceptions of taiping in the early Middle Ages.

\section{Taiping in Han Confucianism}

In Han Confucianism, on the other hand, the image of Supreme Peace related exactly to everything that from the Daoist perspective separated humanity from the primordial unity with nature. In the discourse of scholars $(r u)$, the category of taiping played the role of a referent to the "the good old days": when the political power of the sovereign was strong, all subjects were aware of the obligations

7 萬民歸往而不傷害, 則國家安寧而致太平矣。治身不害神明, 則身安而大壽也 (...) 太平之 世, 人無貴賤。

8 此言天下太平不知仁, 人盡無欲(不)知廉, 各自潔己不知貞。大道之世, 仁義沒。 
arising from their social positions, and this was manifested in rituals and moral conduct, due to which there was order and peace in the state. Such an understanding of taiping is dominant in the youngest of the Classics, Records of Rituals (Liji 禮 記), which put this vision of the era of Supreme Peace into the mouth of Confucius himself (Liji 28:9/1390). ${ }^{9}$ Similar depictions are to be found in the texts associated with the New Text School of Confucianism written in the Western Han period, such as Records of Rituals by Dai the Elder (Da Dai Liji 大戴禮記) and Garden of Sayings (Shuoyuan 說園), with the latter pioneeringly contrasting taiping with an epoch of chaos (luanshi 亂世) (Da Dai Liji 35.40; Shuoyuan 5.11, 13.1). An Outer Commentary to the Master Han's Book of Songs (Hanshi waizhuan 韓詩外傳), another key work of New Text provenance, goes even as far, and states that

In the times of Supreme Peace there were no persons dumb, deaf, lame, one-eyed, feeble, dwarfed, or mutilated. Fathers did not [have to] weep for their sons, nor elder brothers to weep for their younger brothers (...) In the age of Supreme Peace the people, in supplying forced labour, did not go beyond the time [fixed]; men and women did not neglect the time [proper for] mating; filial sons did not neglect the time for nourishing [their parents]. Abroad there were no unmarried men, and in the seclusion of the house there were no dissatisfied women. (Hanshi waizhuan 2:10.19, translated by Hightower 1952, 87, 96, modified $)^{10}$

Importantly, Hanshi waizhuan treats taiping as a historical embodiment of the ideal system of social divisions reflecting concrete prescriptions of Confucian morality and, unlike the vision of datong, it emphasizes that, in their daily activities, the humans of the era of Supreme Peace "did not go beyond" the moral obligations towards their family members. Yet again, we are not told how to reconstitute that social order. The only hint at restoration of this lost paradise in Han Confucianism comes from Abundant Dew of the Springs and Autumns (Chunqiu fanlu

9 南面而立, 夫是以天下太平也。諸侯朝, 萬物服體, 而百官莫敢不承事矣。禮之所興, 眾 之所治也。Of course, Liji is most famous for establishing another utopian ideal, datong, the description of which was also put into the mouth of Confucius. A discussion of datong goes beyond the limits of this paper, but a few things can be observed. First, the concept of datong in premodern thought never referred to the future or even integrated into cyclical views of history, which happened to taiping. Second, its presence outside the Liyun chapter of Liji is marginal, even in Confucianism: whereas Kongzi jiayu literally repeats the Liyun depiction, in Chunqiu fanlu (52.1) datong is rather understood as a "unity of yin and yang" and does not entail any philosophy of history. Lastly, in Mozi, Zhuangzi, the texts of mingjia, and in Wang Chong, the notion of datong refers to "big similarities" (versus "small differences"), being therefore an entirely different philosophical concept.

10 太平之時, 無瘖、https://zh.m.wiktionary.org/zh-hans/\%F0\%A4\%BC\%83、跛、眇、㝼蹇、 侏儒、折短, 父不哭子, 兄不哭弟 (...) 太平之時, 民行役者不踰時, 男女不失時以偶。孝 子不失時以養; 外無曂夫, 內無怨女。 
春秋繁露) attributed to Dong Zhongshu 董仲舒 (179-104 BCE), who argues that taiping will be reached if the emperor returns to the root of the Kingly Way (Chunqiu fanlu 6:2/107), ${ }^{11}$ which probably meant for Dong the entire system of ritual response to Nature (Tian) inscribed into his correlativism, as he also depicts Supreme Peace as the time when divine pneuma ( $q i$ 氣) will again spontaneously flow out of its source (Chunqiu fanlu 78:2/634). ${ }^{12}$ However, given the lack of any vision of the future other than repetition of the cycles of three standards (santong 三統) of white, red, and black (cf. Rogacz 2020,74-78), it is difficult to assume that Dong indeed thought of taiping as breaking out of history, rather than just identifying it with some particular (repeating) epoch.

These visions are echoed in the Eastern Han in such works as Comprehensive [Records] from the White Tiger Hall (Bobutong 白虎通) by Ban Gu 班固 (32-92 CE) and The School Sayings of Confucius (Kongzi jiayu 孔子家語) compiled by Wang $\mathrm{Su}$ 王肅 (195-256 CE), in which the epoch of Supreme Peace is generally identified with the regency of Prince Zhou (c. 1042-1035 BCE). Such a consentaneous and, in fact, purely rhetorical use of the notion of Supreme Peace in the emerging imperial ideology was similar to the way the concept of taiping was understood in Han historiography. Sima Qian 司馬遷 (145-86 BCE), for instance, referred taiping to the former times of pristine peace amongst the people, associated with the reign of $\mathrm{Yu}$ the Great (21st c. BCE?) — the founder of China's first hereditary dynasty. ${ }^{13}$ As Barbara Hendrischke $(2007,9)$ aptly observes, "the major controversy developed around the question as to at which point in time the world had been in a stage of great peace." ${ }^{14}$

Thus the solidifying interpretation of taiping became, however, quite swiftly subjected to criticism. One of its main contesters was Wang Chong 王充 (27-97 $\mathrm{CE}$ ) who, convinced that there are no essential differences in the pneuma ( $q$ i) constituting the people of past and present times, distrusted the Confucian idealization of distant antiquity. Wang was well-aware that the tendency to hyperbolize the past is somewhat natural, and that many of his contemporaries consider everything old as right, but this does not excuse historians, who should investigate whether some claims about the past are true or false (Lunheng 16/232.458.483;

11 反王道之本, 譏天王以致太平。

12 為致太平, 若神氣自通於淵也。It refers to the idea of Grand Vortex (taiyuan 太淵)一the reservoir of primordial pneuma (yuanqi 元氣), associated with yin energy.

13 Interestingly, Sima Qian puts into the mouth of Qin Shi Huangdi a "will to foster Supreme Peace" 欲以興太平 (Shiji 6:41/258). If that were true, the concept of taiping would have already been in use under the Qin, but even then there are no traces of its pre-imperial employment. (Cf. Hendrischke 2007, 5-6).

14 Jia Yi 賈誼 (201-169 BCE), for instance, situated taiping during the rule of Yellow Emperor. 
85/1684-1685). Wang's main argument against the Confucians is that if the main criterion distinguishing taiping is the welfare and absence of wars, then it should rather be concluded that "in fact, Supreme Peace has already come", counting it at the latest from the reign of Han Wendi (190-157 BCE). If, however, the Confucians do not agree with equating taiping with Pax Sinica, then they make unrealistic demands, such that cannot be met by any people, which makes Supreme Peace as such impossible (Lunheng 57/1093-1106). ${ }^{15}$ Emblematically, this criticism comes from the chapter provocatively entitled Praise of the Hans (Xuan Han 宣漢). This notwithstanding, Michael Puett (2005/2006, 280-81) asserts that although Wang Chong was far from idealizing the past, he awaited the advent of the future era of peace, although Puett fails to quote any passages that could validate such a reading. ${ }^{16}$

Obviously, this sort of critique, if not deconstruction, of the ideal of taiping could not have been welcomed by the Confucians, and as a result some New Text Confucians who came after Wang Chong tried to add more philosophical panache to the dominant view of Supreme Peace. He Xiu 何休 (129-182 CE) in his elaboration on the Gongyang Commentary to the Springs and Autumns incorporated his vision of taiping into an exposition of Chinese history in the Chunqiu period, which was divided into three epochs (sanshi 三世). The first of these (the years 722-627 BCE) was the time of decay and chaos (shuai-luan 衰亂), which corresponded with what Confucius knew, based on the records of his native state of $\mathrm{Lu}$. The second one, the epoch of rising peace (shengping 升平; 626-542 BCE), represents what Confucius knew from what he had heard, particularly with regard to the differences between the inhabitants of Central States (Zhongguo 中國) and barbarians. Finally, the last epoch-that of supreme peace (taiping; 541-481 BCE) - ran parallel to the times witnessed by Confucius himself, which were to be a period of blurring the lines between the Chinese and barbarians (Gongyang jiegu 1:26). Undoubtedly, He Xiu's sequence of epochs was of an "ascending" nature, although seeing it as a general theory of progress, as Feng Youlan (1948, 201-2) does, rather exaggerates the case. First, He Xiu's scheme is narrowed down

15 The notion of taiping appears in Wang Chong's Lunheng almost 100 times and there are many minor polemics with its Confucian proponents besides the main line of argumentation. Targeting Dong Zhongshu, for instance, Wang argues that if Supreme Peace entails the harmonization of pneuma ( $q$ i), then no ruler is able to introduce it, as there are no humans capable of influencing the spontaneous transformations of nature, which means that if Supreme Peace ever comes, it will come by itself, by means of spontaneous harmonization of $q i$ without any human intervention (和 氣自至, 太平自立矣; Lunheng 19/319).

16 Puett is rather alone in this view. Hendrischke $(2007,10)$ has no doubts about Wang Chong's "matter-of-fact" and "fairly narrow understanding of the notion of great peace" as something that had been reached. 
to the particular period of Chinese history and was never employed outside of these frames. Second, the universalization of this scheme does not exclude a cyclical interpretation, which was, in fact, much closer to original intentions of $\mathrm{He}$ Xiu. ${ }^{17}$ Interestingly, it is this seemingly perfunctory view that will, partly due to its ambivalence, inspire modern Chinese thinkers at the end of the eighteenth century to rethink the classical Confucian approach to the category of Supreme Peace.

\section{Medieval Pursuits of Supreme Peace}

Surprisingly, the common feature of early Confucian attitudes towards Supreme Peace was to treat it as a strictly descriptive category, whereas Han Daoists were not yet sure if Supreme Peace could indeed be reintroduced and under what precise conditions. As a result, the concept of taiping referred mostly to particular historical times: the remote past before the establishment of culture and political institutions (Daoism), the golden age of monarchical rule that was already the subject of chronicles (Confucianism), or simply the Han dynasty (Wang Chong).

The situation changed with the outbreak of the famous Yellow Turban Rebellion in $184 \mathrm{CE}$, which was initiated by Zhang Jue 張角 (d. 184), a charismatic leader of the Way of Supreme Peace (Taipingdao). Zhang Jue himself was a disciple, and perhaps a relative of, Zhang Daoling 張道陵 (34-156), the founder of the Way of Heavenly Masters (Tianshidao), who just like the above-mentioned Zhang Lu, and even prior to him, relied on the epiphany of the Supreme Lord Lao (Taishang Laojun 太上老君). In his teachings, Zhang Jue heralded the imminent arrival of an era of peace, equality and community of goods, and he also accepted women and barbarians (mainly Huns) into his community (Hendrischke 2007,26). There are many indications that Zhang Jue constructed his view, at least in part, on the work later known as the Scripture of Supreme Peace (Taipingjing). ${ }^{18}$ The text of Taipingjing in its current form, however, was finally shaped in the late sixth century

17 There are a few passages in which He Xiu extrapolates his view beyond the Chunqiu period. One of them is certainly the discussion of the last event recorded in Springs and Autumns, namely the capture of a mysterious qilin 麒麟 ( $481 \mathrm{BCE}$ ), which was for him a definite "sign" of the realization of "great peace". He Xiu continues, however, suggesting that the Qin and early Han brought chaos, and with his remark that the Dao of Confucius was identical to that of emperors Yao and Shun, we may suppose that his view of history was actually much closer to other cyclical conceptions of history that were quite popular in the Eastern Han era. (See Gongyang jiegu 28: 624-28).

18 The two versions of the text existed already under the Han. The shorter, twelve-chapter version, Tianguan li Baoyuan Taipingiing, mentioned in the Book of Han (Hanshu) has been lost, while 58 out of 170 chapters have been preserved of the longer Taiping qingling shu version. The latter was included in the Daoist Canon and become the basis for the 1960 Taipingjing hejiao edition of Wang Ming, which I am drawing on here. 
(Beck 1980, 151, 180) ${ }^{19}$ and the pieces of this extensive anthology, undoubtedly made up from the contributions of multiple authors, circulated throughout the entire period of political chaos, competing with other apocalyptic currents, as evidenced by numerous criticisms of "false prophets" in Taipingjing. A particular object of attack of the Taipinging were various types of messianism, which, historically speaking, inspired peasant rebellions in China to an ever greater degree: be it Buddhist, associated with the belief in the descent of Buddha Maitreya, or the Daoist ones. The latter were presented in works such as the Scripture of Divine Spells from the Most Precipitous Abyss (Taishang dongyuan shenzhou jing 太上洞淵 神咒經), which crowned its colourful visions of the underworld and the plagues accompanying the apocalypse with the image of the descent of a "messiah" named Li Hong 李洪, identified as the incarnation of Lord Lao, who will gather the faithful, called "the seed people" (zhongmin 種民), thus inaugurating the era of Supreme Peace (Seidel 1969/1970, 216-47; 1984, 161-74).

The Taipinging did not share such unequivocal eschatological optimism. In fact it drew an extremely pessimistic image of human nature, which was centred around the idea of "inherited guilt" (chengfu 承負). It is said that that people originally lived in harmony with Heaven and Earth, going without any laws and customs. At some point, evil was committed; this moment, however, is not strictly specified, once estimated at hundreds of thousands of generations ago, another time equated in age with Heaven and Earth themselves (Taipingiing 37:60, 41:32, 72:295, 92:371). ${ }^{20}$ With time, people "added" more and more evil with their deeds. It is stated that each generation passes on to successive generations not only its own faults, but also all the evil that it had inherited, so that the guilt is heavier from generation to generation (Taipingjing 36:52, 37:61, 44:143). Unlike the concept of original sin, it is not only the original fault that is transmitted; contrary to the idea of karma, individual faults are transferred not from person to person, but to the whole of humanity. As Michael Puett $(2008,185)$ notes, this leads to paradoxical consequences: people suffer as a consequence of the evil they did not commit, so they are basically not responsible for what is happening in their time and are in this sense innocent, whereas those who disturbed the primordial state of harmony in which they lived in are to be blamed in the first place. Taipingiing confirms this interpretation, stressing that even if a ruler has unparalleled virtue it will not improve the situation of mankind. Chaos and corruption are not the only misfortunes that affect humanity because of inherited guilt: they also include cataclysms and anomalies (Taipingjing 37:56.60). In this way, Taipingjing radicalized

19 On the other hand, Hendrischke $(2007,4)$ notes that "it has come down to us more directly than have most 'great' texts. It has not been revised and smoothed by generations of editors". 
the Daoist idea of the fall expressed first in Zhuangzi, and then in Huainanzi.

Unlike Huainanzi, however, there are passages in Taipingjing in which a somewhat theistically understood Heaven plays the role of an "executor" of the consequences of inherited guilt and, if necessary, it will not stop even from exterminating the whole human race (Taipingjing 92:370-375). But it is the constant and gradual increase of evil itself that leads to a further escalation of cataclysms and, finally, apocalypse. As a result of droughts and epidemics, humanity is to become completely extinct, so that no human being survives the final "annihilation" (miejin 滅盡). Then the unity of Heaven and Earth will collapse and the whole world will soon thereafter be destroyed. If nothing changes, the arrival of that time is rather imminent (Taipingjing 92:373). Hence, the philosophy of history in the Scripture of Supreme Peace can be justifiably referred to as a millenarian one. However, Stephen Bokenkamp $(1994,61)$ disputes the claim that there was millenarianism in China, as he believes that such a vision is necessarily related to the linear conception of history, while the Chinese were-apparently-preoccupied with cyclical views, thus the notions of "millenarianism" and "apocalypse" can be used only metaphorically in this case. Surprisingly, however, Taipingjing is not mentioned amongst the many Daoist writings to which Bokenkamp refers, in spite of its clearly linear view of history, which fully meets his criteria for millenarianism. Bokenkamp seems here to share the influential yet very outdated opinion of Mircea Eliade, who saw the image of cyclical and fundamentally good cosmos as common among all "primitive" cultures, challenged only by the Jewish idea of linear time (Eliade 1964, 107). In contrast, Anna Seidel, who introduced Daoist messianism, argues that "the longing for paradise on earth (...) is one of the most elementary hopes which lie deeply hidden in man" (Seidel 1984, 161). Unlike Bokenkamp, Livia Kohn has no doubts that Taipingjing is an instance of genuinely Chinese millenarianism, which also led to a major transfiguration of the taiping ideal: "the cyclicality of the mandate of heaven was modified to allow a linear course for history; the idea of Great Peace implied a total break with the preceding age as well as the judgment and destruction of the wicked" (Kohn 1998, 39). Of course, Taipingiing specifies some cycles such as the lifecycle, the seasons, or the cycle of traditional chronology, but the concept of cyclicality does not refer in the "macro" scale to the consequences of guilt, and is actually criticized in this context (Petersen 1990, 28-29).

However, it is still not clear how to situate the eponymous ideal of Supreme Peace in the perspective of the upcoming apocalypse, especially since, due to the remote roots of evil, it is impossible to locate taiping in the distant past. This problem was solved by rejecting the monolinearity of history and assuming that the apocalypse is not the only possible scenario for the end of history. The authors of Taipingjing 
firmly believe that it is possible to build the Supreme Peace in the future and there already exist guidelines on how to make it. It is argued that the various teachings that have emerged throughout history set themselves the task of eliminating evil in the world. Each of these doctrines carries seeds of truth and is not entirely false (Taipingjing 91:348), although, at the same time, each of them does so fragmentarily, and cannot be treated as the depositary of total and absolute truth. Should people follow them in their entirety, the inherited guilt will not cease to accumulate. However, as these teachings spread and become the dominant systems, they do not allow for any criticism, much less an extraction of their doctrines. But the emergence of yet another doctrine is not a solution, either. Taipingjing strongly criticizes any faith in the appearance of a "future sage" houshengren 後聖人 (announced in the Gongyang zhuan) or any figure who is heralded as being able to resolve all the problems of humanity. This would actually escalate Heaven's rage and only accelerate the apocalypse (Taipingjing 27:58, 69:270, 91:350). These fragments, which are clearly directed against the then-dominant, messianistic face of Daoist religion, are rightly identified by Jens $\varnothing$ stergaard Petersen as an instance of the "anti-messianic millenarianism" of the Taipingjing (Petersen 1990, 32).

The most important message, however, is that since each doctrine contains a seed of truth, it is necessary to collect all these pieces from all epochs and combine them into one, "penetrating scripture" dongjijing 洞極經 (Taipingjing 91:349-350). ${ }^{21} \mathrm{It}$ is believed that all people must participate in the process of compiling this scripture: the old and young, women and men, free people and slaves, Chinese and barbarians (Taipingiing 67:255, 86:327, 91:86.348-351). The questions arise as to the criterion for "sifting" truth from lies, and regarding the basis on which future generations would know which elements of human culture should be included in the ultimate moral guide for humanity. This is of course related to the particular morals of Zhang Jue and his followers, which were projected onto a future utopia. However, although theoretically speaking one can distinguish between the epistemological conditions for collating "the ultimate scripture", the ethical system of the Taiping sect, and its socio-political (and historiosophical) vision, in reality the answer was rather simple and it referred to the very same precepts that would enable humanity to succeed in such a unifying endeavour:

The authors of the T[ai]P[ing]J[ing] proclaimed that society had to abolish all habits that prevented its naturelike functioning. They saw a particular need for the general togetherness of all, and even for a certain

21 天下文書, 及人各言一, 或言十數, 而天下之疑事悉自解, 亦無大煩也。但各居其處而言 之, 傅持付上耳。是名為天下集言而共語, 以通達天地之意, 以通達天地之氣, 以除帝王 災害，以利凡民 (...) 天下人共集辭策及古今神聖之文以為洞極經。 
equality between all (...) This togetherness had to be active, as was the cooperation between man, heaven, and earth in the course of the agricultural year. Thus, not to communicate and not to participate was seen as an evil, an idea that led to a number of detailed prescriptions, from the need to convey any knowledge one might have gained to the demand that wealth should be shared and that everyone should take part in productive labor. Everybody, including women and serfs, was part of this social interchange (...) Since great peace meant harmony between nature and men, the need to maintain the integrity of heaven and earth required social reforms. (Hendrischke 2007, 14-15)

The taiping era must thus reflect the universalism accompanying the process of its pursuit. In the state of Supreme Peace there will be equality between men and women, the Chinese and barbarians, and there will be no slaves or bondswomen. In particular, violence against women and infanticide of female newborns will be stopped (Taipingjing 35:34-36, 51:83, 88:333, 91:348.352). Wars and chaos will disappear, and humans will no longer destroy nature, nor will people hoard property, as they will only work to the best of their abilities. ${ }^{22}$ As Petersen argues, the authors (and most probably also the authoresses) of Taipingjing offer the possibility of "jumping out of history" and creating "a world where no change occurs and no change is needed" (Petersen 1990, 32). This notwithstanding, unlike Buddhist and Christian eschatology, Supreme Peace is still pictured as a "Heaven on Earth", realized by the joint efforts of all humanity. It is therefore conceptualized as a final social system in which people continue to live, work and reproduce in full harmony with each other and nature. ${ }^{23}$

Thus understood, this utopian ideal inspired many peasant uprisings and, most importantly, the Taiping Rebellion in the nineteenth century. However, Chinese rulers no less eagerly used the notion of taiping. A native of the Tabgach (Tuoba 拓拔) tribe, the Taiwu emperor of northern Wei 魏太武帝 (408-452), even took the title of "the True Ruler of Supreme Peace" (Taiping zhenjun 太平真君), thereby initiating the practice of adapting the word taiping as an era name (nianbao 年 號). As a result, Chinese emperors of the Tang, Song and Ming Dynasties referred to taiping as their era name as many as ten times. This was probably intended to discredit the utopian project hidden behind this term and to ideologically equate the millenarian ideal with the current political reality.

22 For more details of these images, see Hendrischke (1992, 71-72).

23 In contrast to Huainanzi, Taipingjing is silent on the place of technology in the future utopia, regardless of its great esteem for accumulating and sharing knowledge. 
With few exceptions, the idea of taiping ceased to be an inspiring model for the Chinese philosophers of history (especially those of Daoist provenance) until the end of the eighteenth century. ${ }^{24}$ One of them was Li Gou 李睍 (1009-1059), the teacher of Wang Anshi 王安石 (1021-1086) and the founder of the "practicalist learning” shigongxue 事功學 within broadly understood Neo-Confucianism. Surprisingly, Li Gou believed that Supreme Peace would be more or less identical with the ideal socio-economic system depicted in the Rites of Zhou (Zhouli 周禮), a work traditionally associated with the Old Text School of Confucianism (He Xiu and the majority of the Han Confucian proponents of taiping were of NewText provenance). In his treatise entitled The Rites of Zhou shall lead to Supreme Peace (Zhouli zhi Taiping lun 周禮致太平論), Li Gou describes Supreme Peace as the state in which "there are no kings outside, and the world is one family, each foot of land is a field, and each of the people is treated like a son, the whole country is full of goods and money, like a money bag, while taxes and rentals flow equally from everyone" ( $\mathrm{Li}$ Gou ji 6:76). ${ }^{25} \mathrm{Li}$ Gou's dream, which was certainly a retro-utopia, was, however, as Shan-Yüan Hsieh observes $(1979,104-9)$, rooted in the materialistically understood evolution of civilization. ${ }^{26}$ Following the Hongfan 洪範 chapter of the Documents, Li argues that no political and moral change will be possible if food and goods are not secured. The most important amongst these usable goods (caiyong 財用), often called “commodities”( buo 貨), is money/gold (jin 金) (Li Gou ji 16:136). Hence, in order to enter Supreme Peace, people - specifically peasants — should be given not only their own land, but also money. ${ }^{27}$ And once again, in Li Gou's eyes, this is by no means different from the golden age of the Zhou. While the ancients used money as a means of exchange, later feudal landlords began to treat it as treasure, which, due to their lack of involvement in any kind of labour, could be multiplied only by increasing the fiscal oppression of the people ( $L i$ Gou ji 16:137). The case of Li Gou is, therefore, an intriguing example of developing the Confucian approach to the taiping ideal. Although the concept of taiping still referred to the idealized social system of former kings, Li Gou also argued that Supreme Peace, thus imagined, could also be a

24 In Daoism, one such exception was the Extended Records of Supreme Peace (Taiping guangji 太平廣 記), completed in 978 and designed as a complement to the Imperial Digest of [the Reign of] Supreme Peace (Taiping yulan 太平御覽) of 983, which, however, merely repeat the ideas from the Taipingjing (cf. Kirkland 1993, 47).

25 蓋王者無外, 以天下為家, 尺地莫非其田, 一民莫非其子, 財物之在海內, 如在糓中, 況 於貢賦之入。

26 On Li Gou's historical materialism, see Rogacz $(2021,8-10,13)$.

27 On the details of Li Gou's economic and political project and its later echoes in the Book of Statecraft for Grand Peace (Taiping jingguoshu) 太平經國書 by Zheng Boqian (1128-1192), see Song (2015, 52-77.336). 
future utopia, the possible realization of which entailed severe social criticism that was rather unimaginable for Han Confucians.

\section{Gong Zizhen and Late Imperial Search for Supreme Peace}

The idea of Supreme Peace returned with the renaissance of New Text Confucianism, which took place only during the Qing dynasty, due to the then-famous Changzhou School. One of its representatives, Zhuang Cunyu 莊存與 (1719-1788), contributed to the popularization of the ideas of He Xiu, whereas his grandson and disciple, Liu Fenglu 劉逢祿 (1776-1829), tried to universalize the sequence of the three epochs (sanshi). As Liu states, the sanshi scheme does not refer merely to the Spring and Autumn Period, but repeats itself cyclically (fu ru xunhuan 復如循環) and therefore serves as a model for future generations (Lunyu shuhe 1297:8). Hence, as Elman (1990, 255) notes, “in Liu Feng-lu's hands, this vision of antiquity as the repository for inert precedents was radically transformed. Instead, precedents became part of a vision of future change and reform." This notwithstanding, it has to be emphasized that treating the order of the three epochs as a cyclical pattern rather than a linear scheme of all history implied the postulate that the era of Supreme Peace would be followed by yet another period of chaos. The proposed reforms were, in turn, rather reactionary in nature, and so Liu Fenglu called for a return to ancient feudalism, along with the institution of barons and marquises (zhuhou 諸侯), considering this period the essence of $\mathrm{Su}-$ preme Peace (Liu Libu ji 4: 38).

A view of history similar in terms of its internal structure was later proposed by one of the epigones of the Changzhou school, Song Xiangfeng 宋翔鳳 (1779-1860). Song believed that the order of the three epochs constituted a hidden meaning of not only the Springs and Autumns, but all the other writings of Confucius, including the Analects. Most importantly, however, Song Xiangfeng equated the notion of taiping with the concept of datong from the Liyun chapter, believing that these two terms refer to one and the same era when "people will find peace in their homes, enjoy their work, live to a grand old age, and take advantage of the circumstances" (Daxue guyi shuo 2:12.15). This fusion of two utopian ideals of premodern Chinese philosophy of history had a great impact upon the thought of Kang Youwei 康有為 (1858-1927), although it has to be borne in mind that, just like Liu Fenglu, Song Xiangfeng understood the sequence of three epochs cyclically-as beginning anew from the moment of its completion (Lunyu shuoyi 2:19, 5:3).

The next step towards the universalization of the Confucian idea of taiping was made by Liu Fenglu's most prominent disciple, Gong Zizhen (1792-1841). As 
rightly observed by the editors of his collected works, he might be referred to as the last thinker of the classical era and the first of the modern one (Gong Zizhen quanji, 1). Deeply inspired by the Springs and Autumns, as he himself admits, as early as 1817 Gong starts to think of history in terms of an (at least apparently) linear tripartite scheme. Depending on the various degrees of talent spread among all the members of society, three epochs are distinguished: the epoch of order (zhishi 治世), of chaos (luanshi 亂世), and of decline (shuaishi 衰世) (Gong Zizhen quanji 1:6). This scheme is, however, retrogressive, and it was not until 1819, when Gong begun his studies under Liu Fenglu in Beijing, that the "vector" of his historical vision changed. At this juncture, Gong states that history develops through the epochs of chaos, rising peace and, finally, Supreme Peace, and that this sequence is manifested in all spheres of culture, especially laws, rituals and customs. What is more, Gong believes that the idea of three epochs is exemplified not only in the Springs and Autumns, but also in other Classics: the Hongfan chapter of the Documents, the Liyun chapter of the Records of Rituals, ${ }^{28}$ the Analects, a few parts of the Changes of the Zhou, and even some of the poems from the Songs. Gong's reinterpretation of the Hongfan, included in his Treatise on the Great Meaning of Five Classics from their Beginning to the End (Wujing dayi zhongshi lun 五經大義 終始論), is particularly interesting. By matching each sphere of political activity described in this text with one of the three epochs, Gong argues that food and commodities correspond to the epoch of chaos, then the matters of sacrifices, education, public works and penal code represent the epoch of rising peace, while the emergence of culture (wén 文), following the rise of soldiers and teachers, brings the era of Supreme Peace into being (Gong Zizhen quanji 1:41-48). This scheme works as a diachronic exposition of the dependence of culture upon its material foundations, which will be further developed in Gong's later thought.

Importantly, throughout Wujing dayi zhongshi lun, Gong Zizhen claims that the culture of the Zhou founders was an embodiment of Supreme Peace, if not its first historical instance, which means that the above-described sequence could be treated as cyclical. Wang Jilu $(2002,471)$ argues that this constitutes one of the major contradictions of Gong Zizhen's philosophy of history. Eventually, however, there is no conflict, as Gong openly states that "all history could be divided into three epochs (tong gujin keyi wei sanshi 通古今可以為三世), and the events from the beginning to the end of the Springs and Autumns could also be divided

28 Gong strives to fit the Liyun into the Procrustean bed of the sanshi scheme, despite the fact that the era of datong and its definitive end is followed by the era of Small Prosperity (xiaokang 小康), which results in an essentially retrogressive and pessimistic narrative. Gong seems to be aware of this fact and remains silent about both eras, trying to show that the periods of original chaos and the "ultimate one" (taiyi 太-), which precede the imminent arrival of datong, fall into his progressive order. 
into three epochs" (Gong Zizhen quanji 1:48). This means that, just as the beginning, middle and end can be distinguished both in the scale of the whole process and its singular phases, so the scheme of the three epochs is a universal key to the knowledge of both the entirety of history and its component periods. Gong's pioneering employment of the concept of sanshi with regard to history in general did not come at the expense of a cyclical view, but by virtue of incorporating the latter, which perfectly testifies to the transitional nature of his philosophy of history. As Wang and $\mathrm{Ng}$ rightly point out,

As Gong himself made clear, this temporal trichotomy was after all a repetition of the antique Three Ages, in that its ending point was the age of universal peace, an age which happily replicated that same great golden era of yore. In other words, the paradigm of historical classicality still held sway in Gong's historicism. (Wang and Ng 2005, xx)

An important feature of the epoch of Supreme Peace is that, unlike the previous two epochs, the difference between "the inner" and "the outer" spheres of the country, or in other words, China and the rest of the world, is no longer in force. In order to allay all those who might be concerned that this implies some sort of cosmopolitanism which would be harmful to the raison d'Etat, Gong Zizhen emphasizes that loving and protecting one's country is not in conflict with care for other states, just as the public (gong 公) does not oppose the private (si 私). On the contrary, the public interest will not be satisfied if people do not recognize it as convergent with their private interest: the public and the private have to "mutually elevate" each other (Gong Zizhen quanji 1:92). This idea led Gong to an intriguing vision of history.

In An Essay on the Patrilineage System in Agriculture (Nongzongpian 農宗篇) from 1823, Gong Zizhen argues that when people started to cultivate the soil, in accordance with their intelligence and strength, some of them tilled a foot of land, others two, ten or hundred feet, becoming the "masters" of the respective portion of earth. The establishment of private property involved the rise of inequality: those whose land was broad could afford to meet the wants of their children, and when they were no longer concerned about satisfying their basic needs their behaviour became standardized and known as customs and law. The task of preserving one's property, in turn, entailed a set of rules of conduct, which became honoured as virtues. ${ }^{29}$ Ultimately, all social divisions were sacralized as coming from

29 "If the father was not partial to his eldest son, then he was unkind. If the eldest son was not obliged to his father, then he was unfilial. If the other sons did not honor the eldest son, they would not display brotherly love. If the eldest son did not provide for the other, he was unrighteous. If the father did not distinguish between the eldest and the remaining sons, then the hundred mou estate 


\section{Heaven (zu shen qi shuo yu Tian 卒神其說於天) (Gong Zizhen quanji 1:49).}

In An Essay on Equal Distribution (Pingjunpian 平均篇), written in the same year, Gong additionally points out that "people's hearts" reflect their economic situation: while the rich enjoy glory, the poor weaken each day, becoming more and more irate, envious, and miserable. Therefore, economic inequality is the decisive cause of the decline of states in history: "the greater the gulf between those who have too much and those who have too little, the faster the state declines; but if that gulf is somewhat narrowed, good government will be somewhat more quickly achieved" (Gong Zizhen quanji 1:78, translated by Borei 1977, 282-83). Gong Zizhen believes that in remote antiquity achieving equality was the ideal of the rulers, but with time these "small inequalities gradually led to great inequalities" (jian zhi da buxiangqi 漸至大不相齊). As a witness of the Eight Trigrams uprising of 1813, Gong Zizhen urges the Qing emperor to follow the example of the ancient rulers and to make "adjustments according to the time"- the equalization of land, which in his opinion could be achieved in less than ten years (Gong Zizhen quanji 1:78-80). However, the rise of inequalities after the reform will be inevitable, as the human desire to possess and protect private property is ineradicable. Just as the golden age of ancient rulers was an epoch of reconciling the public with the private, so the future era of Supreme Peace is a time of harmonizing people's private needs with the publicly oriented objectives of the centralized power. The time of the Zhou - an instance of the era of Supreme Peace within a portion of history-serves as a model for the future implementation of this utopia.

Knowledge of history, therefore, plays a significant role in the realization of Supreme Peace. As Gong Zizhen puts it, "the great tendency [of history] that cannot be skipped ahead” (buneng tiao guijin zhi dashi 不能逃古今之大勢) irreversibly leads towards an increasing number of historical events and their complexity (Gong Zizhen quanji 5:334). This fact should be reflected in historical records, which ought to include not only political and military history, but also economic history, the history of rites, customs, literature, and art, including archeological research, local histories and the records of ethnic minorities (Gong Zizhen quanji 1:80-81, 4:265267.281). In this way, by extending the resource of historical experience to the utmost, politicians would be given the largest "instrumentarium" possible. Gong's idea of the tendency of history shows that in spite of all the concessions made to the cyclical views of history, he viewed the general historical process in rather linear terms.

Transforming the concept of the three epochs into a universal scheme, Gong recognized the golden age of Chinese history as the first and paradigmatic instance 
of the epoch of Supreme Peace, or that of culture, preceded by the era of economic and political changes. This meant, though, that culture (morality and religion in particular) reflects and sanctions the economic differences created at the dawn of history. This calls for the reform whose aim is to bring about equalization, which is to be initiated by the emperor with the help of state historians. It will be probably done in the ultimate era of Supreme Peace which, given the necessary trend towards accumulation of knowledge, will coincide with the greatest amount and level of culture. The visions of irreversible and linear progress that were about to come to China a few decades later were never so close to the domestic views of history, and it is quite natural that in his encounter with Western theories of progress Kang Youwei drew on the ideas of Gong Zizhen and New Text Confucianism. ${ }^{30}$ Commenting upon this influence of Gong Zizhen, Federico Brusadelli writes that "this may suggest that a linear vision of history had already emerged out of the Chinese Classical tradition, prior to any significant impact by Western theories", albeit for Gong Zizhen "there is no assurance of eternity, for the age of Supreme Equality might easily collapse again into an age of Chaos, thus starting again the (natural) cycle of history" (Brusadelli 2020, 21-22).

\section{Conclusion}

The paper discusses the premodern Chinese views of Supreme Peace and demonstrates that the idea of taiping was unknown prior to the Han dynasty, originally referring to idealized remote past. Whereas the Daoists identified it with the primordial, pre-cultural unity of humans and nature, Han Confucians equated Supreme Peace with the harmonious and hierarchical social system under the sagacious rule of one of the first Chinese emperors (or Confucius for He Xiu). The latter being the case, the notion of taiping was reduced to a purely descriptive category, which was then employed by official historiography but ridiculed in the critical thought of Wang Chong. With works such as the Huainanzi and the Xiang'er commentary to Laozi, the Daoists started to argue that it is possible to restore the Supreme Peace under new historical conditions, with help of gods, a visionary emperor, or due to the efforts of unified humanity. The last option was taken up and developed in a systematic way in the Taipingjing, which offered a detailed depiction of the future utopia of freedom, equality, and fulfilment. For the authors of Taipingjing, however, Supreme Peace has not yet been present in any period of history, since from its inception humanity accumulates and

30 It should be emphasized that Kang Youwei used the terms taiping and datong rather interchangeably, while his most detailed depictions of future utopia refer, in fact, to the notion of Supreme Peace, cf. Brusadelli (2020, 61-63, 86-91). 
transmits "inherited guilt" to subsequent generations. In the search for a recipe for taiping, all people, regardless of their origins and gender, have to gather the seeds of liberating truth from all world teachings and implement them in social life. However, with the radicalization of the project of Supreme Peace, the notion of taiping was soon utilized by imperial propaganda and disappeared from the dominant philosophical discourse. An exception to this rule was Li Gou, who envisaged Supreme Peace as an ideal socio-economic system resulting from endowing peasants with land and money. A similar vision was later expressed by Gong Zizhen, who revived He Xiu's scheme of the three epochs, treating it as a universal structure of the historical process in terms of both its totality and all its phases. For Gong, who argued that morality, customs and religion reflect and solidify the economic status of the people, Supreme Peace must entail land equalization and the reduction of social inequalities. In contrast to Daoism, both $\mathrm{Li}$ and Gong saw taiping mostly as a socio-economic project, which in fact developed the position represented by the Han Confucians. In the same way, Li Gou and Gong Zizhen also believed that these reforms would restore the golden age of the Zhou rather than break with all hitherto known institutions. Similarly to Taipingjing, however, Gong described Supreme Peace as an epoch of culture, seeing it as the culmination point of the increase and development of human knowledge. With such an approach, the premodern Chinese views of taiping became significantly close to Western progressivism, which explains why Gong's ideas and New Text Confucianism in general became such good allies of the utopian project of Kang Youwei and his followers.

\section{References}

\section{Chinese editions}

Dadai Liji 大戴禮記. Chinese Text Project. Accessed August 1, 2021.ctext.org/ da-dai-li-ji.

Daxue guyi shuo大學古義說. Huang Qingjingjie 皇清經解 edition. 1870. Guangzhou: Xuehai tang.

Gong Zizhen quanji 竟自珍全集 (Collected Works of Gong Zizhen). 1975. Shanghai: Shanhai renmin chubanshe.

Gongyang jiegu 公羊解詁 (Explanations of the Gongyang Commentary). 1999. In: Chunqiu Gongyanghuan 春秋公羊傳, Shisanjing zhushu 十三經注疏, vol. 8. Beijing: Beijing daxue chubanshe.

Heshang Gong Laozi: Heshanggong zhangju 河上公章句. 1998. Beijing: Beijing wenhua chubanshe. 
Huainanzi: Huainanzi jiaoshi 淮南子校釋. 1997. Beijing: Beijing daxue chubanshe.

Liji: Liji zhengyi 禮記正義, Shisanjing zhushu十三經注疏, vol. 6. 1999. Beijing: Beijing daxue chubanshe.

Liu Libu ji 劉禮部集. Ruzang 儒藏 edition. 2016. Beijing: Beijing daxue chubanshe.

Lunheng: Lunheng zhushi 論衡注釋. 1979. Beijing: Zhonghua shuju.

Lunyu shuhe 論語述何. Huang Qing jingjie 皇清經解 edition. 1870. Guangzhou:

Xuehai tang.

Lunyu shuoyi 論語說義. By Song Xiangfeng 宋翔鳳. Huang Qing jingjie edition.

1870. Guangzhou: Xuehai tang.

Shiji 史記. 1963. Beijing: Zhonghua shuju.

Shuoyuan 說苑. Chinese Text Project. Accessed August 1, 2021. ctext.org/ shuo-yuan.

Taipingjing: Taipingjing hejiao 太平經合校. 1960. Beijing: Zhonghua shuju. Zhuangzi: Zhuangzi jishi 莊子集釋. 1961. Beijing: Zhonghua shuju.

\section{Secondary literature}

Beck, B. J. Mansvelt. 1980. “The Date of the Taiping Jing.” Toung Pao 66: 149-82. Bokenkamp, Stephen. 1994. "Time After Time: Taoist Apocalyptic History and the Founding of the T'ang Dynasty." Asia Major 7 (1): 59-88.

Bokenkamp, Stephen. 1999. Early Daoist Scriptures. Berkeley: University of California Press.

Borei, Dorothy. 1977. "Decline and Reform: A Study of the Statecraft Essays of Kung Tzu-chen.” PhD diss., University of Pennsylvania.

Brusadelli, Federico. 2020. Confucian Concord. Reform, Utopia and Global Teleology in Kang Youwei's Datong shu. Leiden: Brill.

Chen Guying. 2016. The Philosophy of Life. A New Reading of the Zhuangzi. Leiden: Brill.

Eliade, Mircea. 1964. The Myth of the Eternal Return. Translated by Willard Trask. New York: Pantheon Books.

Elman, Benjamin. 1990. Classicism, Politics, and Kinship: The Ch'ang-chou School of New Text Confucianism in Late Imperial China. Berkeley-Los Angeles: University of California Press.

Feng Youlan. 1948. A Short History of Chinese Philosophy. Edited by Derk Bodde. New York: Free Press.

Hendrischke, Barbara. 1991. "The Concept of Inherited Evil in the Taiping jing." East Asian History 2: 327-37.

.1992. "The Daoist Utopia of Great Peace.” Oriens Extremus 35: 61-91. 
2007. The Scripture on Great Peace: The Taiping jing and the Beginnings of Daoism. Berkeley et al: University of California Press.

Hightower, James R. 1952. Han Shih Wai Chuan: Han Ying's Illustrations of the Didactic Application of the Classic of Songs. Cambridge, MA: Harvard University Press.

Kirkland, Russell. 1993. “A World in Balance: Holistic Synthesis in the T'ai-p'ing kuang-chi." Journal of Song-Yuan Studies 23: 43-70.

Klein, Esther. 2010. "Were there 'Inner Chapters' in the Warring States? A New Examination of Evidence about the Zhuangzi." T'oung Pao 96 (4/5): 299-369. doi.org/10.1163/156853210X546509.

Kohn, Livia. 1998. "The Beginnings and Cultural Characteristics of East Asian Millenarianism." Japanese Religions 23 (1-2): 29-51.

Lai, Karen. 2015. "Daoism and Confucianism." In Dao Companion to Daoist Philosophy, edited by Liu Xiaogan, 489-511. Dordrecht et al.: Springer.

Le Blanc, Charles. 1985. Huai nan tzu. Philosophical Synthesis in Early Han Thought: The Idea of Resonance (Kan-ying) With a Translation and Analysis of Chapter Six. Hong Kong: Hong Kong University Press.

Petersen, Jens Østergaard. 1990. "The Anti-Messianism of the Taiping Jing." Studies in Central and East Asian Religions 3: 1-41.

Pokora, Timoteus. 1961. "On the Origins of the Notions T'ai-p'ing and Ta-T'ung in Chinese Philosophy." Archiv Orientalni 29 (3): 448-54.

Puett, Michael. 2005/2006. "Listening to Sages: Divination, Omens, and the Rhetoric of Antiquity in Wang Chong's Lunheng." Oriens Extremus 45: 271-81.

2008. "The Belatedness of the Present: Debates over Antiquity during the Han Dynasty." In Perceptions of Antiquity in Chinese Civilization, edited by Dieter Kuhn, and Helga Stahl, 177-90. Heidelberg: Edition Forum.

.2014. "Sages, Creation, and the End of History in the Huainanzi." In The Huainanzi and Textual Production in Early China, edited by Sarah Queen, and Michael Puett, 269-90. Leiden/Boston: Brill.

Rogacz, Dawid. 2020. Chinese Philosophy of History: From Ancient Confucianism to the End of the Eighteenth Century. London: Bloomsbury Academic.

— 2021. "Historical Materialism in Medieval China: The Cases of Liu Zongyuan (773-819) and Li Gou (1009-1059).” Asian Philosophy 1-17. doi. org/10.1080/09552367.2021.1924437.

Seidel, Anna. 1969/1970. "The Image of the Perfect Ruler in Early Taoist Messianism: Lao-tzu and Li Hung." History of Religions 9 (2/3): 216-47.

- 1984. “Taoist Messianism.” Numen 31 (2): 161-74.

Shan-Yüan, Hsieh. 1979. The Life and Thought of Li Kou (1009-1059). San Francisco: Chinese Materials Center. 
Shih, Vincent Yu-Chung. 1967. The Taiping Ideology: Its Sources, Interpretations and Influences. Seattle: University of Washington Press.

Song, Jaeyoon. 2015. Traces of Grand Peace. Classics and State Activism in Imperial China. Cambridge, MA and London: Harvard University Press.

Wang, Jilu 王记录. 2002. Zhongguo shixue sixiang tongshi. Qingdai juan 中国史 学思想通史。清代卷 (A Comprehensive History of Chinese Historiographical Thought: Qing Times volume). Hefei: Huangshan shushe.

Wang, Q. Edward, and On-cho Ng. 2005. Mirroring the Past: The Writing and Use of History in Imperial China. Honolulu: University of Hawai'i Press.

Whitbeck Judith. 1980. “The Historical Vision of Kung Tzu-chen (1792-1841).” PhD diss., University of California. 